
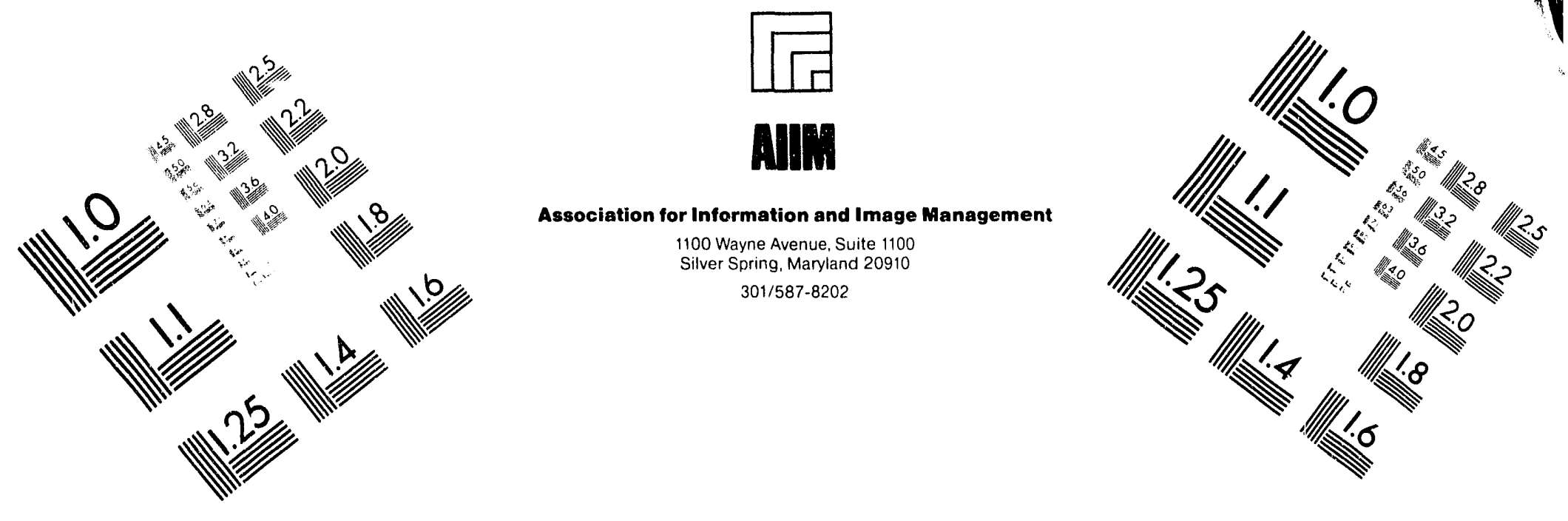

\title{
Centimeter
}

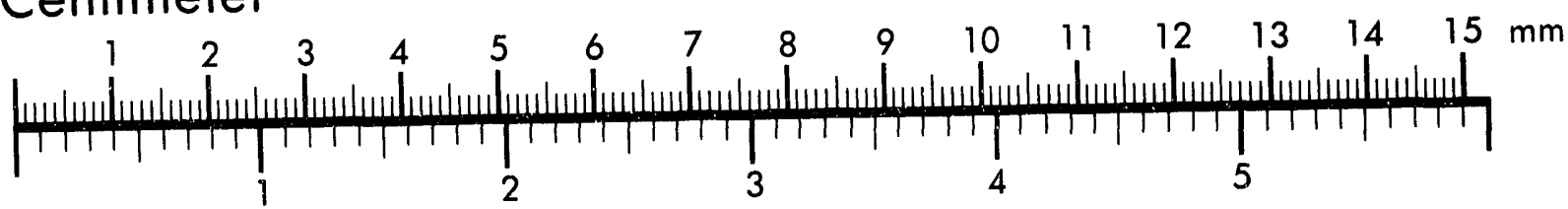
Inches
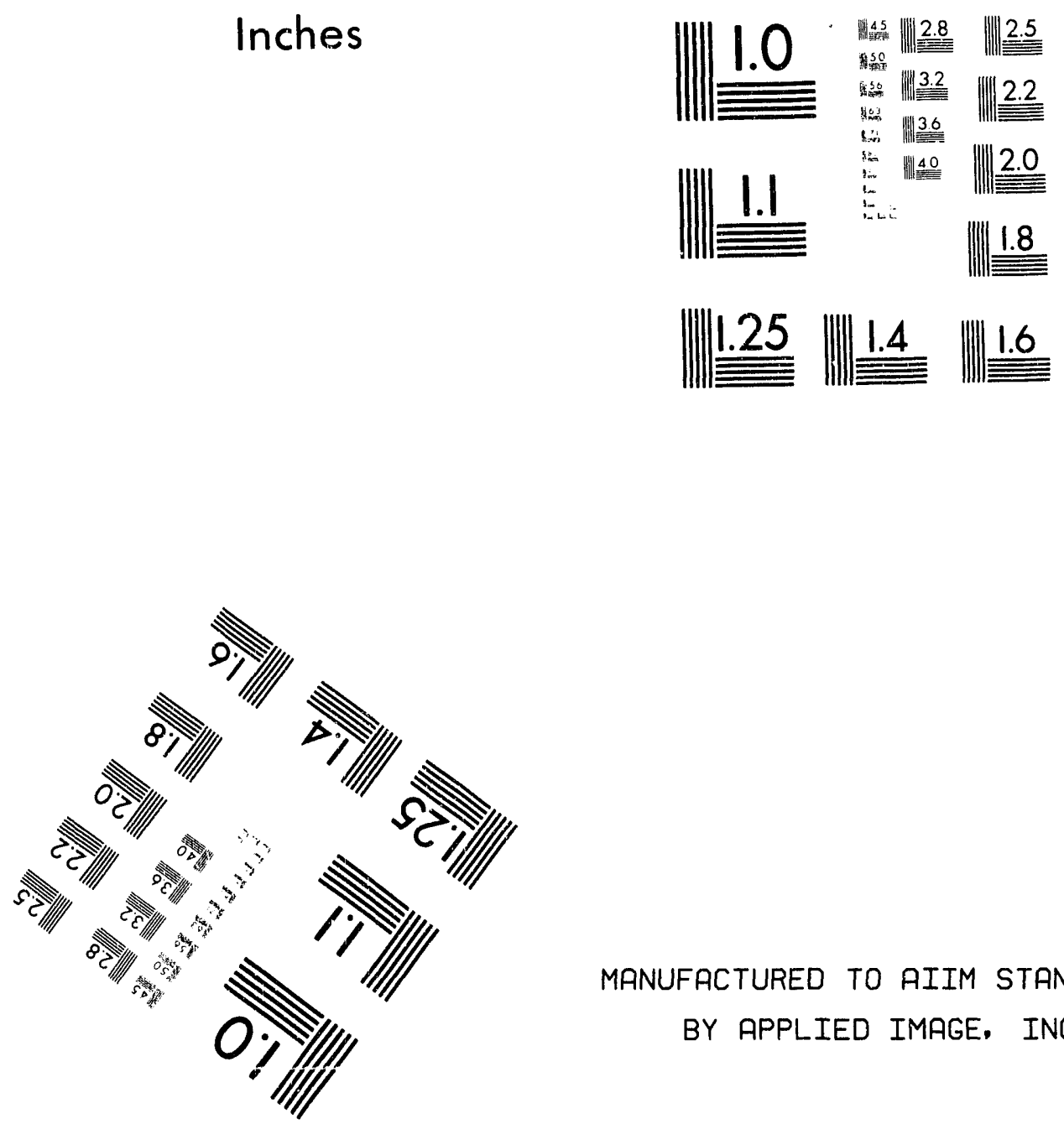

MANUFACTURED TO AIIM STANDARDS

BY APPLIED IMAGE. INC.

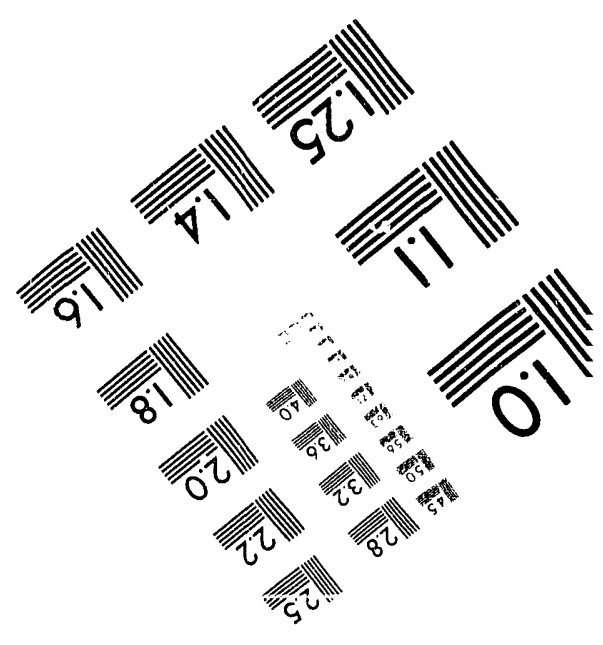



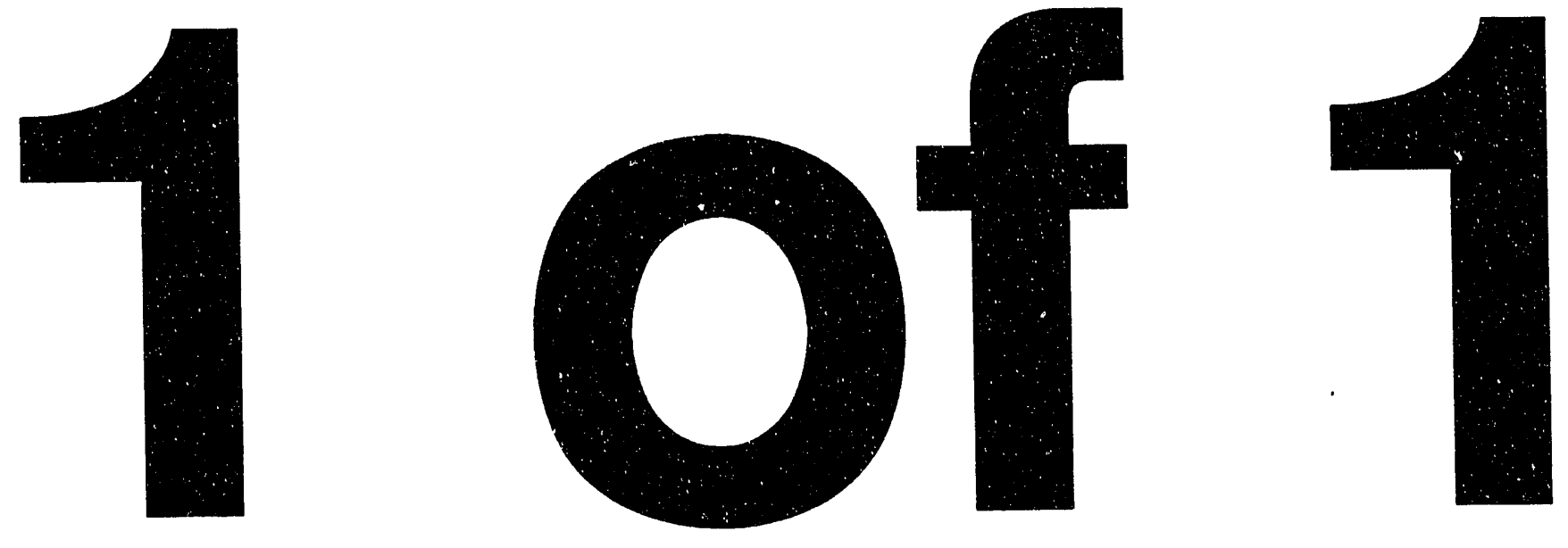


\section{Impact on the Steam Electric Power Industry of Deleting Section 316(a) of the Clean Water Act: Capital Costs}

Environmental Assessment and Information Sciences Division Argonne National Laboratory

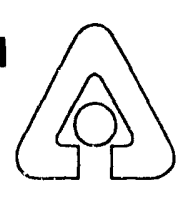

Operated by The University of Chicago, under Contract W-31-109-Eng-38, for the

United States Department of Energy 


\section{Argonne National Laboratory}

Argonne National Laboratory, with facilities in the strites of Illinois and Idaho, is owned by the United States govermment, and operated by the University of Chicago under the provisions of a contract with the Department of Energy.

This technical report is a product of Argonne's Environmental Assessment and Information Sciences Division. For information on the division's scientific and engineering activities, contact:

Director, Environmental Assessment and Information Sciences Division

Argonne National Laboratory

Argonne, Illinois 60439-4815

Telephone (708) 252-3759

\section{Disclaimer}

This report was prepared as an account of work sponsored by an agency of the United States Govemment. Neither the United States Govemment nor any agency thereof, nor any of their employees, makes any warranty, express or implied, or assumes any legal liability or responsibility for the accuracy, completeness, or usefuiness of any information, apparatus, product, or process disclosed, or represents that its use would not infringe privately owned rights. Reference herein to any specific commercial product, process, or service by trade name, trademark, manufacturer, or otherwise, does not necessarily constitute or imply its endorsement, recommendation, or favoring by the United States Govemment or any agency thereof. The views and opinions of authors expressed herein do not necessarily state or reflect those of the United States Govemment or any agency thereof.

Available to DOE and DOE contractors from the Office of Scientific and Technical Information, P.O. Box 62, Oak Ridgo, TN 37831; prices available from (615) $576-8401$.

Available to the public from the National Technical Information Service, U.S. Department of Commerce, 5285 Port Royal Road, Springfield, VA 22161. 


\section{Impact on the Steam Electric Power Industry of Deleting Section 316(a) of the Clean Water Act: Capital Costs}

by J.A. Veil

Environmental Assessment and Information Sciences Division, Argonne National Laborctory, 9700 South Cass Avenue, Argonne, Illinois 60439

Work sponsored by United States Department of Energy,

Assistant Secretary for Domestic and International Energy Policy 


\section{CONTENTS}

ACKNOWLEDGMENTS $\ldots \ldots \ldots \ldots \ldots \ldots \ldots \ldots \ldots \ldots \ldots$

NOTATION $\ldots \ldots \ldots \ldots \ldots \ldots \ldots \ldots \ldots \ldots \ldots \ldots \ldots \ldots \ldots \ldots$

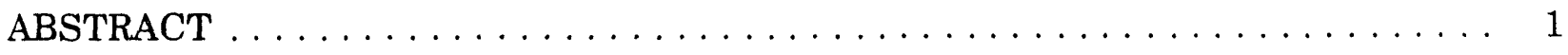

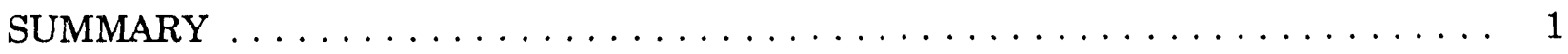

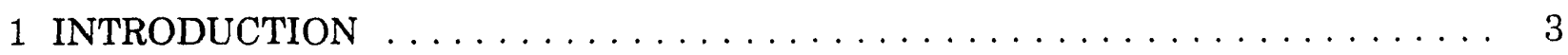

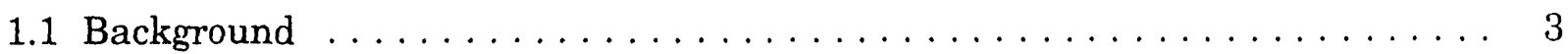

1.1.1 Use of Cooling Water in Power Generation . . . . . . . . . . . . . 3

1.1.2 Overview of Controls on Thermal Discharges $\ldots \ldots \ldots \ldots \ldots$

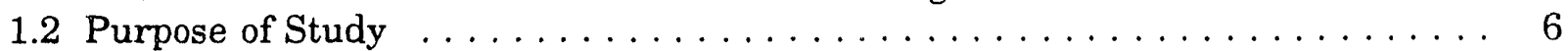

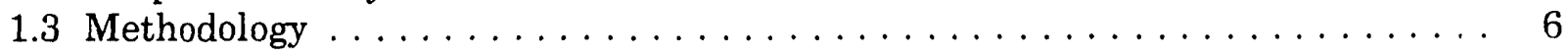

2 AFFECTED FACILITIES $\ldots \ldots \ldots \ldots \ldots \ldots \ldots \ldots \ldots \ldots \ldots$

2.1 Plants Currently Holding Variances $\ldots \ldots \ldots \ldots \ldots \ldots \ldots \ldots \ldots$

2.2 Plants in Other Regulatory Situations $\ldots \ldots \ldots \ldots \ldots \ldots \ldots \ldots$

2.3 Other Affected Industries $\ldots \ldots \ldots \ldots \ldots \ldots \ldots \ldots$

3 ALTERNATIVES TO A SECTION 316(a) VARIANCE . . . . . . . . . . . . . . 10

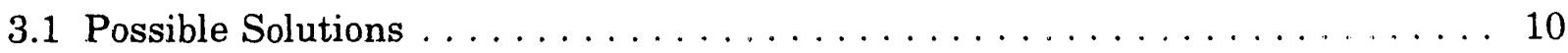

3.2 Cooling Towers $\ldots \ldots \ldots \ldots \ldots \ldots \ldots \ldots \ldots \ldots \ldots \ldots \ldots \ldots \ldots$

4 COSTS TO RETROFIT POWER PLANTS WITH COOLING TOWERS $\ldots \ldots \ldots$. . 12

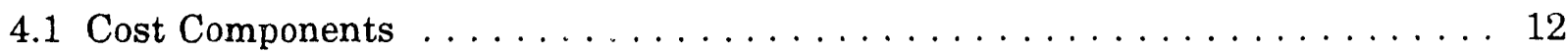

4.2 Operations and Maintenance Costs $\ldots \ldots \ldots \ldots \ldots \ldots \ldots \ldots$

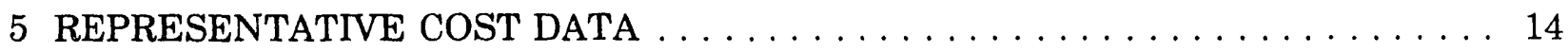

5.1 New England Power $\ldots \ldots \ldots \ldots \ldots \ldots \ldots \ldots \ldots \ldots \ldots \ldots$

5.2 GPU Nuclear . . . . . . . . . . . . . . . . . . . . . . . . . . . . 14

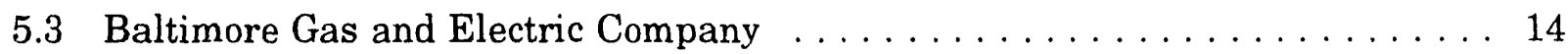

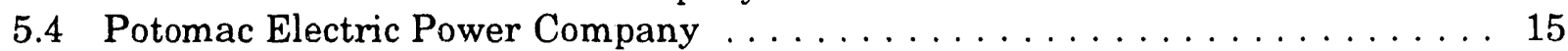

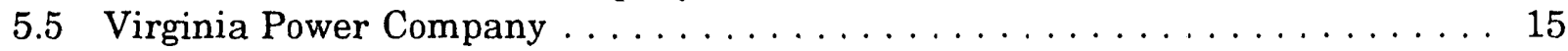

5.6 Carolina Power and Light $\ldots \ldots \ldots \ldots \ldots \ldots \ldots \ldots \ldots \ldots \ldots \ldots \ldots$

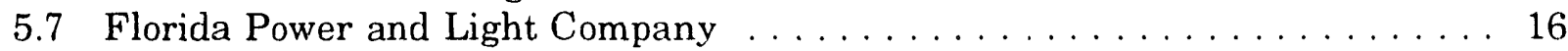

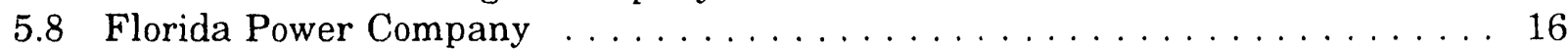

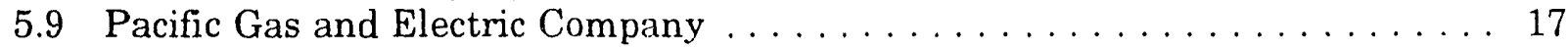

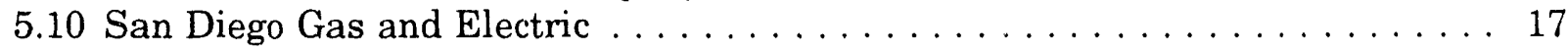

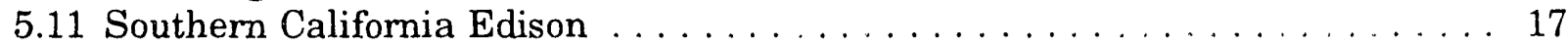

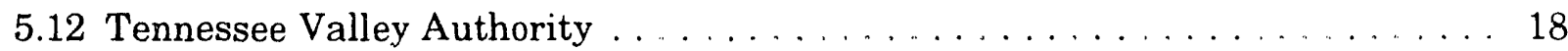

5.13 American Electric Power Service Corporation . . . . . . . . . . . . . . 19

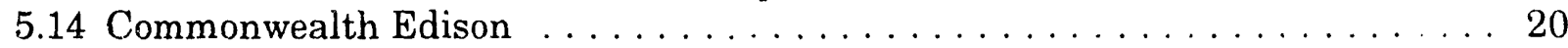




\section{CONTENTS (Cont.)}

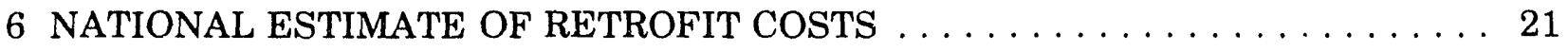

6.1 Summary of Data Gathered . . . . . . . . . . . . . . . . . . 21

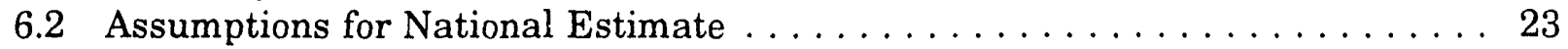

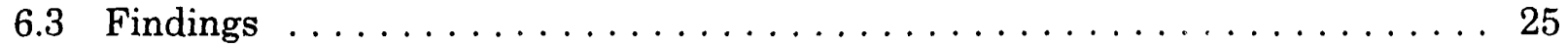

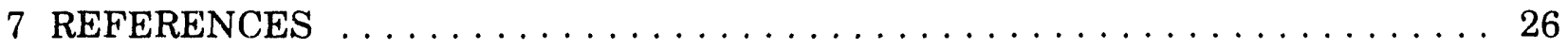

\section{TABLES}

1 Retrofitting Costs for TVA's Coal-Fired Plants Operating

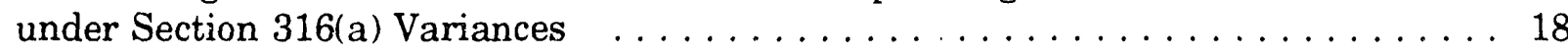

2 Retrofitting Costs for AEP's Plants Operating under Section $316($ a) Variances $\ldots \ldots \ldots \ldots \ldots \ldots \ldots \ldots \ldots$

3 Summary of Retrofitting Costs for Fossil-Fuel Units . . . . . . . . . . . . . 22

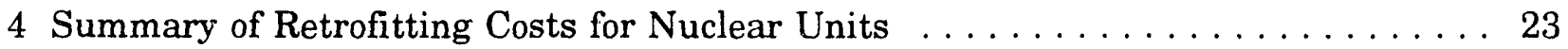

\section{FIGURES}

1 Capital Cost to Retrofit Fossil-Fuel Units with Cooling Towers . . . . . . . . . . . . . 24

2 Capital Cost to Retrofit Nuclear Units with Cooling Towers . . . . . . . . . . . . . 24 


\section{ACKNOWLEDGMENTS}

The Edison Electric Institute provided a prepublication draft copy of Stone \& Webster (1992), which was useful for background information and comparison. Cost estimates for the individual plants were provided by the 14 power companies included in the study. C. Richard Bozec of Edison Electric Institute and Kristy A.N. Bulliet and Steven J. Koorse of Hunton \& Williams (representing the Utility Water Act Group) were instrumental in coordinating industry review of the draft report. 


\section{NOTATION}

\section{ACRONYMS, INITIALISMS, AND ABBREVIATIONS}

$\begin{array}{ll}\text { AEP } & \text { American Electric Power Service Corporation } \\ \text { BAT } & \text { best available technology } \\ \text { BG\&E } & \text { Baltimore Gas and Electric } \\ \text { CE } & \text { Commonwealth Edison } \\ \text { CFR } & \text { Code of Federal Regulations } \\ \text { CP\&L } & \text { Carolina Power and Light } \\ \text { CWA } & \text { Clean Water Act } \\ \text { EPA } & \text { U.S. Environmental Protection Agency } \\ \text { EPRI } & \text { Electric Power Research Institute } \\ \text { EEI } & \text { Edison Electric Institute } \\ \text { FP\&L } & \text { Florida Power and Light Company } \\ \text { FPC } & \text { Florida Power Company } \\ \text { GPU } & \text { GPU Nuclear } \\ \text { NEP } & \text { New England Power } \\ \text { NPDES } & \text { National Pollutant Discharge Elimination System } \\ \text { NSPS } & \text { new source performance standards } \\ \text { O\&M } & \text { operations and maintenance } \\ \text { PEPCO } & \text { Potomac Electric Power Company } \\ \text { PG\&E } & \text { Pacific Gas and Electric } \\ \text { SCE } & \text { Southern California Edison } \\ \text { SDG\&E } & \text { San Diego Gas and Electric } \\ \text { TVA } & \text { Tennessee Valley Authority } \\ \text { UDI } & \text { Utility Data Institute } \\ \text { VEPCO } & \text { Virginia Electric Power Company }\end{array}$

\section{UNITS OF MEASURE}

$\begin{array}{ll}\mathrm{ft} & \text { foot (feet) } \\ \mathrm{kW} & \text { kilowatt(s) } \\ \mathrm{m} & \text { meter(s) } \\ \mathrm{MW} & \text { megawatt(s) } \\ \mathrm{ppm} & \text { part(s) per million }\end{array}$




\title{
IMPACT ON THE STEAM ELECTRIC POWER INDUSTRY OF DELETING SECT:ON 316(a) OF THE CLEAN WATER ACT: CAPITAL COSTS
}

by

\author{
J.A. Veil
}

\begin{abstract}
.
Many power plants discharge large volumes of cooling water. In some cases, the temperature of the discharge exceeds state thermal requirements. Section 316(a) of the Clean Water Act (CWA) allows a thermal discharger to demonstrate that less stringent thermal effluent limitations would still protect aquatic life. About $32 \%$ of total U.S. steam electric generating capacity operates under Section 316(a) variances. In 1991, the U.S. Senate proposed legislation that would delete Section 316(a) from the CWA. This study, presented in two companion reports, examines how this legislation would affect the steam electric power industry. This report describes alternatives available to nuclear and coal-fired plants currently operating under variances. Data from 38 plants representing 14 companies are used to estimate the national cost of implementing such alternatives. Although there are other alternatives, most affected plants would be retrofitted with cooling towers. Assuming that all plants currently operating under variances would install cooling towers, the national capital cost estimate for these retrofits ranges from $\$ 22.7$ billion to $\$ 24.4$ billion (in 1992 dollars). The second report ${ }^{*}$ quantitatively and qualitatively evaluates the energy and environmental impacts of deleting the variance. Little justification has been found for renoving the Section 316(a) variance from the CWA.
\end{abstract}

\section{SUMMARY}

Many power plants discharge large volumes of once-through cooling water; in some cases, the temperature of the discharge exceeds state thermal requirements. Section 316(a) of the Clean Water Act (CWA) allows a discharger to demonstrate that the otherwise applicable thermal effluent limits are more stringent than necessary to protect aquatic life and that other, less stringent effluent limitations would protect those organisms. About $32 \%$

* Veil, J.A., et al., 1993, Impact on the Steam Electric Power Industry of Deleting Section 316(a) of the Clean Water Act: Energy and Environmental Impacts, report ANL/EAIS-5, Argonne National Laboratory, Argonne, ill, January. 
of the total U.S. steam electric generating capacity (or about 189,000 megawatts [MW]) operates under Section 316(a) variances.

In 1991, U.S. Senate staff members prepared and circulated legislation proposing that Section 316(a) be deleted from the CWA and that the existing variances be nullified. This study examines how the steam electric power industry would be affected if existing Section 316(a) variances were no longer valid. The results are presented in two companion reports. This report considers the alternatives that a plant currently operating under a variance could pursue and estimates the national capital costs of implementing these alternatives and continuing to operate without variances.

The second report (Veil et al. 1993) examines the environmental benefits, environmental impacts, and energy costs of building cooling towers at many of the plants that currently use once-through cooling under a Section 316(a) variance. Such a conversion would decrease energy output by an estimated $1.0-4.6 \%$ at fossil-fuel plants and $1.0-5.8 \%$ at nuclear plants. The cost of additional generation to replace this lost output is estimated to be $\$ 11.4$ billion to $\$ 18.4$ billion (in 1992 dollars) over 20 years. The estimated cost of building additional generating capacity is $\$ 1.4$ billion to $\$ 5.3$ billion in 1992 dollars. The environmental benefits of eliminating the variance are minimal.

For this report, information on costs was obtained by surveying a number of power companies in different parts of the country. Thirty-eight plants representing 14 power companies were evaluated during this study. Together, they account for $21 \%$ of the national generating capacity at risk $(39,086 \mathrm{MW}$ out of $189,000 \mathrm{MW})$.

Although a variety of alternatives exist, the vast majority of affected plants would be retrofitted with closed-cycle cooling systems that employ one or more cooling towers. This study assumes that all plants losing the variance would install cooling towers. The national capital cost estimates for retrofitting all units currently operating under Section 316(a) variances range from $\$ 22.7$ billion to $\$ 24.4$ billion in 1992 dollars.

The Edison Electric Institute recently sponsored a study (Stone \& Webster 1992) that used a different methodology to prepare cost estimates. Its estimate of the national capital costs to retrofit plants with cooling towers is $\$ 28.9$ billion in 1992 dollars. The wide range of assumptions used in both studies has introduced some uncertainty into the national cost estimates. However, even if the cost estimates are several times too high, the cost impact on the power industry of losing the Section 316 (a) variance is still very large.

To accurately depict the total cost burden to the power industry, capital costs must be combined with operations and maintenance $(O \& M)$ costs and the costs of replacing lost power (including extra fuel and capital and $O \& M$ costs for new production capacity). The cost of power replacement is analyzed in the companion report (Veil et al. 1993).

Given the extremely high costs, very minimal benefits, and expected environmental impacts if the Section 316(a) variance were eliminated, little justification has been found for deleting Section 316(a) from the CWA. 


\section{INTRODUCTION}

\subsection{BACKGROUND}

\subsubsection{Use of Cooling Water in Power Generation}

Water is used in many industrial applications for cooling machinery or for condensing steam. The largest industrial user of cooling water is the steam electric power industry. At nuclear and fossil-fuel power plants, electricity is generated by heating purified water to create steam. The steam is used to drive turbines, which in turn drive the generators that produce electricity. After leaving the turbines, the steam passes through a condenser, which has multiple tubes and a large surface area. A large volume of cool water circulates through the tubes, absorbing heat from the steam. As the steam cools and condenses, the temperature of the water rises. The condensers are designed to produce a vacuum at the outlet end of the turbine, which increases the efficiency of the system: the lower the initial temperature of the cooling water, the larger the vacuum that can be produced and the greater the efficiency. Therefore, in some cases, the change in water temperature between intake and discharge is quite large.

Most power plants use either once-through cooling or closed-cycle cooling. Oncethrough cooling systems withdraw large volumes of water from a river, lake, estuary, or ocean; pump the water through the condenser; and return it to the same or a nearby body of water. Closed-cycle cooling systems ${ }^{1}$ rely on a cooling tower and basin, cooling pond, or cooling lake. Water is withdrawn from the cooling tower basin, pond, or lake; pumped to the condenser; and then returned to the basin, pond, or lake. Since some water evaporates in this process, the concentrations of certain constituents increase. To maintain proper concentrations, a portion of the recirculated water is discharged as "blowdown," and fresh water is added. More information on these systems is presented in Section 3.

\subsubsection{Overview of Controls on Thermal Discharges}

During the 1970s, thermal discharge issues were considered very important because of concerns about the effects of heat on aquatic life. The first major effort to control thermal discharges is found in the 1972 amendments to the Federal Water Pollution Control Act, also known as the Clean Water Act (CWA). The CWA classifies heat as a pollutant, and permit limits can be based on either heat or temperature.

The CWA directs states to develop water quality standards for the pollutants it identifies, and most states have water quality standards for thermal pollution. The CWA (in Section 301) also directs the U.S. Environmental Protection Agency (EPA) to publish effluent

1 In this report, the term "closed-cycle cooling" means "cooling tower" unless some other type of closed cooling system is specifically mentioned. 
guidelines for different industrial categories. The EPA set technology-based guidelines for the steam electric power industry on October 8, 1974 (39 Federul Register 36186; 40 Code of Federal Regulations [CFR] Part 423).

In the EPA's guidelines, the best available technology (BAT) requirements for existing sources and the new source performance standards (NSHS) specified no discharge of heat from the main condensers of power plants except:

- From blowdown from a recirculating cooling water system; or

- From cooling ponds or lakes (or if ponds or lakes were under construction).

BAT requirements allowed the following additional exceptions from the "no discharge of heat" rule:

- Insufficient land is available for a mechanical draft cooling tower;

- Total dissolved solids exceed 30,000 parts per million (ppm) and property not under the control of the operator is located within $150 \mathrm{~m}$ of the proposed cooling tower site; or

- The plume from a cooling tower would cause an aviation hazard.

Various aspects of these national technology-based controls on heat were challenged by the power industry. A group of electric utilities sued EPA over a variety of thermal issues. Although EPA's Section 316(a) regulations were upheld, the court remanded the guidelines for effluent limitations for heat (Appalachian Power Co. v. Train, 545 F. 2d 1351 [4th Cir., 19761). EPA has never adopted any other national technology-based effluent limits on heat or temperature. Today, all technology-based limits for heat or temperature are derived on a case-by-case basis.

In addition to EPA guidelines, some states have developed their own thermal discharge regulations. Maryland has one of the most active state programs for evaluating thermal discharge effects. Dischargers must meet water quality standards for temperature within $50 \mathrm{ft}$ of the discharge point (or some other mixing zone ${ }^{2}$ approved by the state in special circumstances). If the discharger cannot meet the required temperature, the company may conduct more extensive hydrothermal plume mapping studies. The dimensions of the thermal plume are compared to various criteria to determine if the discharge is acceptable. If the discharger still is unable to meet the requirements of the state standards, including mixing zones, the company must then conduct biological studies to demonstrate that a Section 316(a) variance is warranted.

2 A mixing zone is a limited area surrounding a discharge point in which the effluent mixes with the receiving water; generally, water quality standards must be met at the edge of the mixing zone rather than at the discharge point. 
Many other states do not have such a formal process for assessing thermal discharges, but nearly all states have either statewide or site-specific standards for mixing zones. Some states have established site-specific water quality standards for temperature or have otherwise established water quality standards that take into account existing power plant discharges.

However, the limits set by EPA and the states can be exceeded in some cases. Under Section 316(a) of the CWA, the states or EPA can issue variances that allow thermal dischargers to operate outside the limits if the discharger can demonstrate that the otherwise applicable thermal effluent limits are more stringent than necessary to protect the organisms in and on the receiving water body, and that the other less stringent effluent limitations would protect those organisms. Tle variance does not eliminate the need to consider other impacts of the use of cooling water in addition to direct thermal impacts. Section 316(b) addresses intake impacts such as impingement and entrainment ${ }^{3}$ by requiring that:

the location, desizn, construction, and capacity of cooling water intake structures reflect the best technology for minimizing adverse environmental impact.

This report is concerned only with situations covered by Section 316(a), so Section 316(b) will not be discussed any further.

The power industry has spent millions of dollars on demonstrating that the requirements of Section 316 are met at their generating stations. One direct benefit of the hundreds of studies is that knowledge of ecosystem dynamics and of the life histories, abundance, and distribution of aquatic organisms has been advanced substantially. As information accumulated from the Section 316 studies, it was generally recognized that thermal impacts on biota were less significant than originally thought. The legislative and regulatory focus on water pollution control shifted away from thermal issues to control of toxics and nutrients. As a result, the regulated community did not anticipate that the U.S. Senate CWA reauthorization bill (S. 1081), a major legislative proposal introduced in May 1991, would contain language that deleted Section 316.

In addition to deleting the Section 316(a) variance, the May 1991 draft of S. 1081 limited mixing zones to no more that. $1,000 \mathrm{ft}$, although the thermal plumes of many power plants extend beyond that distance. In December 1991, Senate staff members released an updated version of S. 1081. This bill maintained the deletion of the Section 316(a) variance and also prohibited mixing zones altogether for most pollutants, including temperature and heat.

3 Impingement refers to the situation in which organisms are trapped on screens or other devices covering the inlet of the cooling water pipe. Entrainment refers to the situation in which organisms are drawn into the inlet of cooling water pipe. In both cases, the organisms may subsequently be injured or killed. 


\subsection{PURPOSE OF STUDY}

Many power companies relied on the Section 316(a) variance in siting and operating their plants. At many power plants, studies were done that demonstrated that once-through cooling water discharges were not harming aquatic c ${ }^{\prime}$ mmunities, and the plants were granted Section 316(a) variances. Many other plants are able to comply with state water quality standards at the edge of a mixing zone and do not require a variance. However, if S. 1081 is enacted as currently written, not only would existing Section 316(a) variances be voided, but many plants that currently rely on mixing zones in meeting requirements would need to change their operations, because such mixing zones would be prohibited as well. This study investigates the impact on the power industry of losing the Section 316(a) variance.

The study was conducted in two parts. The present report examines the number of plants that would be affected by loss of their Section 316(a) variances, available options, and costs associated with retrofits and changes in plant operations. A companion report (Veil et al. 1993) considers the environmental benefits, environmental impacts, and energy costs of deleting the Section 316(a) variance.

\subsection{METHODOLOGY}

Cost estimates were generated by obtaining estimates from a number of power companies in different parts of the country. These companies were asked to provide their own estimates of how much it would cost to retrofit their plants with cooling towers or to implement other solutions to deal with the loss of the variance. If the data were available, they also reported on installation costs for existing cooling towers in their systems, even if they were original installations and not retrofits. The results of this survey were subjected to a regression analysis, and several cost rates (in dollars per kilowatt) were derived. The cost rate was then multiplied by the total affected generating capacity to get a national estimate.

The Edison Electric Institute (EEI) has sponsored a study (Stone \& Webster 1992) that considers the same issue but uses a different methodology to estimate costs. That study estimates the cost to retrofit two hypothetical power plants with cooling towers. A hypothetical fossil-fuel plant would receive mechanical-draft towers, while a hypothetical nuclear plant would receive natural-draft towers. The cost for the new towers in dollars per kilowatt is scaled up to the national affected production capacity, resulting in a national capital cost estimate. Both methodologies have limitations. Clearly, the estimates can only be made to within an order of magnitude, since the cost of retrofitting plants with cooling towers is very site-specific. Although cooling towers represent the most likely avenue for achieving compliance, some sites cannot use cooling towers because of space limitations. Other plants are older and have low capacity factors. When utilities are faced with retrofit costs along with Clean Air Act and other requirements, they may retire these older plants rather than upgrade them. The only way to generate a precise estimate would be to conduct a detailed cost analysis for every plant that would be affected. Most utilities have not invested this level of effort at this early stage. 


\section{AFFECTED FACILITIES}

To obtain a national estimate of the cost to the power industry if Section $316(\mathrm{a})$ variances were eliminated, it was first $n$ ecessary to determine how many plants would be affected, including those that are currently operated under variances and those that are currently exempt from regulation for various reasons.

\subsection{PLANTS CURRENTLY HOLDING VARIANCES}

Most power plants constructed in this country since the mid-1970s have relied on cooling towers, but there are many older generating units that still use once-through cooling and that may therefore be affected by the proposed legislation. These plants are located throughout the country. The cases described in Section 5 include plants in New England, the Mid-Atlantic region, Florida, California, the Great Lakes region, and the interior Midwest and South regions.

According to Stone \& Webster (1992), approximately 679 units would be affected if the Section 316(a) variance were lost. These units have a combined generating capacity of roughly 189,000 megawatts (MW), which represents $32 \%$ of the total steam electric generating capacity in the United States. Of those 189,000 MW, approximately 43,000 MW are generated by nuclear plants and approximately 146,000 MW are generated by fossil-fuel plants. The source of Stone \& Webster's data on the power industry was the Power Statistics Database, which is maintained by the Utility Data Institute (UDI) for EEI. ${ }^{4}$

\subsection{PLANTS IN OTHER REGULATORY SITUATIONS}

There are two situations that could affect some plants' status in relation to thermal discharge regulations, and in turn affect the cost estimates reported here. The first is that a Section 316(a) variance is good only for the life of a National Pollutant Discharge Elimination System (NPDES) permit. When the permit must be renewed, ecological conditions at the discharge location may have changed. The second is that in some states, some plants are exempted by regulation from having to meet applicable thermal standards. If these regulations change, more plants might be affected by provisions of Section 316(a).

In the first situation, plants may be required to supply revised information during NPDES permit renewal. A note at the end of 40 CFR 125.72 states:

At the expiration of the permit, any discharger holding a Section 316(a) variance should be prepared to support the continuation of the variance with studies based on the discharger's actual operation experience.

1 This database represents the best set of data available, but it is not completely up to date. UDI is in the process of updating the database. 
In some cases, regulators do not ask for detailed documentation when deciding whether to continue the variance, but they have the power to do so.

Generally, there are only two cases in which new documentation is needed: if plant operations have changed or if the ecology of the receiving water body has changed. The first case is rare; but, with the progress made in reducing pollutant loads in receiving waters, the second situation is beginning to arise. Veil (1989) documents the tremendous reductions in industrial pollutant loadings that occurred in the Maryland portion of Chesapeake Bay between the early 1970s and the mid-1980s, and the concomitant increases in abundance and diversity of benthic organisms over the same period of time. Fish and macroinvertebrate distributions were not included in that paper, but it is not unrealistic to expect changes in those trophic levels as well. With a wider range of organisms at risk in receiving waters, regulatory agencies may feel the need to require new demonstrations that thermal dischargers are protecting aquatic organisms.

If many plants are asked to redo these demonstrations, some of them may not be able to justify the Section 316(a) variance, given the change in ecological conditions. For those plants, the issue of whether Section 316(a) is included in the CWA, and whether a variance would be available, would be irrelevant. However, it is worth noting that plants in this position may still qualify for alternate thermal limits that are less restrictive than statespecified water quality standards, but more restrictive than limits based on Section 316(a).

In the second regulatory situation, which has not been thoroughly researched, some states have adopted site-specific water quality standards or otherwise tailored their standards to allow older plants or plants that have low capacity factors to continue discharging withouc needing a Section 316(a) variance. In some states, these plants are simply exempted by regulation from having to meet applicable thermal standards. In other states, water quality standards are written in such a way as to provide site-specific temperature standards that allow thermal discharges to continue without a Section 316(a) demonstration. If these standards were to change, more plants might require a variance.

Both of these issues have the potential to change the number of power plants that could operate under a Section 316(a) variance. The first issue is likely to decrease the number of plants, and the second issue could either increase or decrease the number of plants operating under the variance. Such a shift in the number of plants and total affected megawatts of capacity would influence the national capital cost of eliminating the variance, although the number of plants potentially affected by these issues is small. In the absence of data to quantify the impact of these issues on the number of plants affected by deletion of the variance, the estimated national capital cost will be calculated for a total affected generating capacity of 189,000 MW (Stone \& Webster 1992). 


\subsection{OTHER AFFECTED INI)USTRIES}

While most high-volume cooling water dischargers are power plants, other industries also operate facilities that discharge cooling water. And, in some cases, relatively small thermal dischargers may still affect small receiving streams. Although this report focuses on the steam electric power industry, it is useful to consider these other facilities.

To find out how many facilities in other industries are operating under Section 316(a) variances, a telephone survey was made of the trade associations for several primary industrial categories. Representatives of the American Petroleum Institute, the Chemical Manufacturers Association, the American Iron and Steel Institute, the Aluminum Association, and the National Council of the Paper Industry for Air and Stream Improvement expressed little knowledge of Section 316(a) variances and did not know if any of their members operated under the variances (Carwile 1992, Fidler 1992, Gillespie 1992, Laffley 1992, Steiner 1992). This result does not mean that no facilities in these industries relied on such variances; rather, it does mean that the national trade associations were unaware of any specific instances.

There is evidence that some states are granting Section 316(a) variances to other industries. The state of Maryland has granted Section 316(a) variances to Bethlehem Steel's Sparrows Point Plant, Amstar Sugar's Baltimore Refinery, the Baltimore RESCO waste-toenergy plant, and Nevamar's decorative laminate plant (Maryland DHMH 1985, 1986a; MDE 1989; Maryland DHMH 1986b). The first three are large facilities that discharge to Baltimore Harbor, but Nevamar is a smaller facility that discharges to a recreational trout stream. The state of Indiana has issued a Section 316(a) variance to an Alcoa Aluminum plant in Newburg (Indiana State Board of Health 1985). Attempts to identify other nonpower facilities with Section 316 (a) variances were not successful. 


\section{ALTERNATIVES TO A SECTION 316(a) VARIANCE}

\subsection{POSSIBLE SOLUTIONS}

If a generating station is unable to continue discharging under a Section 316(a) variance, the utility must select another solution. While there are a variety of alternatives, few are universally practical. The following paragraphs discuss several of the possible solutions.

Retiring plants - In some cases, the utility may elect to retire the plant. Typically, such plants are very old, and the expense of retrofitting them with thermal control measures cannot be justified. This solution is not expected to be adopted very frequently nationwide.

Shedding load - Under this similar, but less dramatic, alternative, the plant produces less power and the resulting discharge is enough cooler that no variance is necessary. A variation of this practice is seasonal operation. For the cooler months of the year, the plant discharges and meets all applicable thermal requirements; however, during the warmer months, the discharges are reduced or discontinued. This solution is not expected to be adopted very often because many power companies cannot afford the loss of generated power, especially during the warmer months.

Changing discharge structure - Some plants may choose to continue to use oncethrough cooling by switching from a surface discharge structure, such as a canal, to a deepwater outfall structure. The pipe would either end in deep water or would employ a high-rate diffuser, or both. In either case, the heated water and ambient water would mix more readily, minimizing the zone of elevated temperature, and the heated water would emerge farther away from the surface layer that supports much of aquatic life. This solution is not always practical because the receiving waters are not large enough for the alteration to make a significant difference.

Blending unheated water - Some power companies try to reduce discharge temperatures in the discharge canal by blending unheated intake water with the heated water coming from the condensers. While this does help to reduce the overall temperature, the added impingement and entrainment resulting from the additional pumping may outweigh the benefit of reduced temperatures. This solution must be carefully evaluated on a case-by-case basis and may not be practical in many cases.

Using cooling structures - Cooling ponds or lakes can be used, but they require large amounts of space. If power companies cannot use Section 316(a) variances, it is much more likely that they will move toward cooling towers. 


\subsection{COOLING TOWERS}

Cooling towers represent a much more feasible solution. On the basis of information provided by the utilities queried for this study, most fossil-fuel plants would use mechanicaldraft cooling towers, while most nuclear plants would use natural-draft towers. Generally, it becomes more economical to switch to natural-draft towers as the plant capacity increases above $600 \mathrm{MW}$ (Aull 1992). Whether this will be true in any given case will depend on a variety of site-specific factors.

In a typical cooling tower, hot condenser water is pumped to the top of the fill material in the tower, where it spreads into a thin layer and falls to the bottom of the tower. While the water is moving downward, it comes into contact with air moving upward and some of the heat in the water is transferred to the air through evaporation. The cooled water returns to the recirculating system, and the heated and moisture-laden air exits through the top of the tower. In this process, water is lost through evaporation and must be replaced with makeup water. Also, dissolved constituents become concentrated through evaporation. To avoid excessive concentrations of certain constituents, part of the recirculating water is removed as blowdown. This volume of water must also be replaced.

Another possible cooling structure is a helper cooling tower', which some plants use to cool a portion of the once-through flow. This type of system could be effective in cases where the once-through discharge temperature is fairly close to the allowable temperature.

A third possibility is dry cooling tower systems, which transfer heat directly to the air without using evaporation of water as the heat transfer mechanism. However, they have not yet been used to any great extent in the United States (EPRI 1991). Generally, they are far more expensive to construct, require an extremely large amount of power to run, extract a much higher energy penalty, and are noisy. Where water is in short supply, however, dry cooling systems may be used in the future.

In all closed-cycle systems, the temperature of the water returning to the condenser is not as cool, on the average, as water withdrawn for once-through cooling. This temperature difference makes the generating system less efficient. The same amount of fuel produces less power, which means the utility must purchase additional power, or, if it has excess plant capacity, it must burn more fuel. 


\section{COSTS TO RETROFIT POWER PLANTS WITH COOLING TOWERS}

In this study, it is assumed that all plants losing the variance will be retrofitted with cooling towers, which is the most feasible solution in most cases (Section 3). Although other solutions will be selected for some small percentage of the plants, those solutions will also have costs associated with them. This section discusses the different elements that go into the total cost of a retrofitting job.

\subsection{COST COMPONENTS}

As mentioned in Section 1.3, cooling tower design and retrofitting costs are very sitespecific. The layout of a site is very important in determining the location of the tower. The distance of the tower from the condenser and the makeup water source will determine the amount of piping and pumping that is necessary.

The climate at the site is also critical in determining the size of the tower. A cooling tower operates on the principle of evaporation, and no tower can cool water below the wet-bulb temperature of the air. The wet-bulb temperature is a measure of the temperature of air saturated with water. When air is fully saturated, no more evaporation will occur; therefore, the cooling tower cannot provide more cooling. Depending on the local wet-bulb temperature and how close to that temperature the plant is designed to operate, the costs can change substantially. below:

The many different component costs of retrofitting a cooling tower are summarized

- Cost of the tower materials and construction;

- Cost of the cooling tower basin;

- Cost of engineering surveys to site the tower, identify existing buried structures, and prepare the site;

- Cost to demolish and/or close intake structure and cooling system components that are no longer needed, and costs to construct any new intake structures or components needed;

- Cost to obtain federal, state, and local permits, including the cost of environmental impact studies;

- Cost to replace piping, valves, pumps, and cundenser to meet the higher pressure requirements of a cooling tower system;

- Cost to supply new electrical service to tower and pumps; 
- Cost to replace power lost when the plant is shut down for retrofitting activities beyond the routine maintenance outage period; and

- Cost to provide chemical treatment of recirculating water.

This list of costs shows that a retrofitting job is much more complicated than simply purchasing and erecting a cooling tower. Section 5 provides some actual data on these costs. The total cost of the project is generally several times higher than the cost of the tower itself.

One other cost associated with retrofitting a plant with a cooling tower is the cost for additional power. Since the recycled water has a higher average temperature than a comparable once-through cooling system, the vacuum produced by the turbine is diminished and the plant is unable to generate as much power. Second, the additional high-pressure pumps, fans, and chemical water treatment system require more power than did the original once-through cooling water pumps. The plant managers have several options. They can operate the plant with lower net power output, or, in some cases, they can run it more frequently or at a higher temperature, which means it must burn additional fuel to maintain output. In either case, there is an energy cost associated with the retrofitting of cooling towers. This energy cost is examined in greater detail in Veil et al. (1993).

\subsection{OPERATIONS AND MAINTENANCE COSTS}

The components of a cooling tower will require additional operations and maintenance (O\&M). The O\&M costs include labor, materials and supplies, and operating expenses. The pumps, valves, and piping must be inspected regularly. Preventive maintenance is necessary to avoid plant outages. Some of the components of a cooling tower will wear out periodically and must be inspected and replaced. The structural members, fill media, and drift eliminators require regular surveillance. .

The contaminants in the recirculated water become concentrated as water evaporates from the tower. To avoid clogging of the piping, which causes inefficient heat transfer, the water must be treated with a variety of biocides, corrosion inhibitors, and scale preventers. O\&M of a water treatment system involves costs for chemicals, monitoring, and operation.

Stone \& Webster (1992) estimates that annual O\&M costs are about $0.7 \%$ of the capital cost of retrofitting. This figure appears to be reasonable, although it represents only a small component of the total project cost. No additional estimate will be derived for O\&M costs. 


\section{REPRESENTATIVE COST DATA}

To estimate the national costs of eliminating the Section 316(a) variance, power companies from different parts of the country were contacted to find out how they would deal with losing the variance. Their proposed solutions and cost estimates are discussed in the following sections. When costs were given in other than 1992 dollars, the Construction Cost Index from Engineering News Record (1992) was used to convert the costs to 1992 dollars.

The cost estimates described below are in most cases not formal, engineering-based calculations, but less formally derived approximations. Numerous factors must be taken into account in developing cost estimates. Because it is unclear exactly which factors were considered by the power companies that supplied cost data, some of the cost estimates presented below may not accurately reflect the entire capital cost of retrofitting.

\subsection{NEW ENGLAND POWER}

New England Power's (NEP's) Manchester Street Station is a fossil-fuel plant that operates under a Section 316(a) variance. The plant currently produces 132 MW but has approval to increase capacity to $455 \mathrm{MW}$. The cost estimates are based on the higher capacity. The cost of retrofitting the Manchester Street and the neighboring South Street plants with cooling towers is $\$ 16.8$ million in 1990 dollars. Since the Manchester Street plant has $82 \%$ of the combined generating capacity of the two plants, $82 \%$ of the cooling tower costs are apportioned to that plant.

There is no source for additional fresh water to be used as makeup water at this site, and NEP estimated the cost of a desalination plant at $\$ 27.6$ million in 1988 dollars. This cost was also multiplied by $82 \%$. Both costs were converted to 1992 dollars, which resulted in a total estimated cost of $\$ 38.6$ million (DeHart 1992).

\subsection{GPU NUCLEAR}

GPU Nuclear (GPU) operates the Oyster Creek plant in central New Jersey on the Atlantic coast. This nuclear plant generates $640 \mathrm{MW}$ of electricity and has applied for a Section 316(a) variance. GPU estimates that it would cost $\$ 150$ million in 1992 dollars to build a cooling tower. This estimate is tentative, and GPU is reconsidering it in light of additional data (Kunkle 1992).

\subsection{BALTIMORE GAS AND ELECTRIC COMPANY}

The Baltimore Gas and Electric Company (BG\&E) operates three plants with Section 316(a) variances. Crane (376 MW) and Wagner (989 MW) are fossil-fuel plants, and Calvert Cliffs is a nuclear plant. All plants would build cooling towers if the variance were 
no longer available. The estimate in 1992 dollars for such retrofitting at Crane is $\$ 30$ million and for Wagner, $\$ 70$ million. No estimates have been made recently for Calvert Cliffs.

BG\&E also operates several older plants that have been exempted in the past from thermal variance requirements but that are now being required to perform Section 316(a) demonstrations, as discussed in Sections 2 and 3. BG\&E intends to retire these plants in the next few years for environmental compliance reasons (mainly because of their inability to meet forthcoming air quality requirements) (Bauereis 1992).

\subsection{POTOMAC ELECTRIC POWER COMPANY}

The Potomac Electric Power Company (PEPCO) operates iwo fossil-fuel plants that currently have Section 316(a) variances. Both plants would retrofit cooling towers if the variance were no longer available. Two units at the Chalk Point plant, which together generate $710 \mathrm{MW}$, use once-through cooling. The cost of installing cooling towers there was estimated in 1989 dollars as $\$ 232$ million for mechanical-draft towers and $\$ 270$ million for natural-draft towers. After conversion to 1992 dollars, these costs are $\$ 246$ million for mechanical-draft and $\$ 286$ million for natural-draft towers. A later estimate that included O\&M costs, lost power, and increases in outages was an annual cost of $\$ 60 / \mathrm{kW}$ in 1991 dollars.

PEPCO has not made any estimate of the cost to retrofit their Dickerson plant with a cooling tower (Bailey 1992).

\subsection{VIRGINIA POWER COMPANY}

The Virginia Power Company (VEPCO) operates two nuclear plants that currently operate under Section 316(a) variances. The North Anna plant (1,618 MW) and the Surry plant (1,562 MW) would both have cooling towers installed if the variance were deleted. The estimated cost in 1992 dollars is $\$ 326$ million for North Anna and \$335 million for Surry (White 1992).

\subsection{CAROLINA POWER AND LIGHT}

Carolina Power and Light (CP\&L) operates the Brunswick Steam Electric plant, a nuclear plant with two units totaling 1,642 MW, on the estuary of the Cape Fear River in North Carolina. This plant does not currently have a Section 316(a) variance and does not anticipate needing one in the future. The regulators have been concerned about the plant's impingement and entrainment impacts; therefore, as part of an extensive study, an estimate was made of the cost to install cooling towers. The estimated cost is $\$ 111$ million in 1980 dollars or $\$ 168$ million in 1992 dollars (Greeson 1992). 


\subsection{FLORIDA POWER AND LIGHT COMPANY}

The Florida Power and Light Company (FP\&L) operates plants with a variety of cooling alternatives. Several plants use cooling ponds with discharges; another uses a closed cooling canal. One plant has installed a mechanical-draft cooling tower. Several plants use once-through cooling, one with a diffuser, another with a deep water discharge, and a third that meets thermal discharge requirements without any modifications. Three other plants operate under Section 316(a) variances.

There are certain limitations to installing cooling towers at the FP\&L plants. Florida's energy shortage precludes the option of retiring plants and makes the energy penalty caused by cooling towers undesirable. Many of the plants are older facilities surrounded by urban areas. Problems with plume drift, lack of space, and land use could impede the approval of permits for cooling towers. Finally, the receiving waters near some of FP\&L's plants are home to the manatee, an endangered species. The manatee relies on year-round warm water, which is augmented by thermal discharges during the winter months. Thus, any reduction in or elimination of once-through cooling discharges could affect manatee populations.

Nevertheless, FP\&L has prepared an estimate of the cost of retrofitting its Cape Canaveral ( $864 \mathrm{MW}$ ), Fort Myers ( $597 \mathrm{MW}$ ), and Cutler (235 MW) plants with cooling towers. The cost in 1992 dollars is $\$ 28$ million, $\$ 25$ million, and $\$ 26$ million, respectively. FP\&L also estimated the capital cost at the three plants for air-cooled condensers, a form of dry cooling tower, at $\$ 338$ million. These costs do not reflect the cost of power replacement during the time the cooling tower is being installed and the plant is shut down (Perkins 1992).

\subsection{FLORIDA POWER COMPANY}

The Florida Power Company's (FPC's) Crystal River plant has five units, three of which use once-through cooling. Units 1 and 2 are coal-fired and Unit 3 is nuclear. The other two units use closed-cycle cooling. Makeup water for the cooling towers is withdrawn from the discharge canal for Units 1, 2, and 3, and tower blowdown is returned to the discharge canal. Downstream from this point, half of the total flow in the discharge canal will be cooled by four helper cooling towers, which are now being installed. The cost for the helper towers is estimated at $\$ 100$ million.

FPC estimates that to install completely closed-cycle cooling for either Unit 3 ( $890 \mathrm{MW}$ ) or for Units 1 and 2 combined (964 MW total) would cost $\$ 253$ million in 1991 dollars or $\$ 256$ million in 1992 dollars. The cost for the nuclear unit (Unit 3 ) does not reflect the more complicated licensing procedures for a nuclear plant; consequently, FPC indicated that if it elected to add a cooling tower, it would be installed on Units 1 and 2 rather than on Unit 3 (Pardue 1992). 


\subsection{PACIFIC GAS AND ELECTRIC COMPANY}

The Pacific Gas and Electric Company (PG\&E) has three fossil-fuel plants currently discharging under Section 316(a) variances - Moss Landing (558 MW), Pittsburgh (1,302 MW generated with once-through cooling), and Contra Costa (1,260 MW). PG\&E has not analyzed alternatives and costs in detail, but it believes that it would install mechanicaldraft cooling towers at all three plants, if that approach were cost-efficient. Its estimate for retrofitting cooling towers on all affected units at the three plants in 1992 dollars is approximately $\$ 53$ million, $\$ 143$ million, and $\$ 110$ million, respectively.

Mechanical-draft cooling towers were retrofitted at Pittsburgh Power Plant Unit 7, a $740-\mathrm{MW}$ unit, in 1976 . The cost was $\$ 16.3$ million in 1976 dollars. This cost is an underestimate in that the retrofit job did not involve replacement of the existing condenser and conduit system (Walton 1992).

\subsection{SAN DIEGO GAS AND ELECTRIC}

San Diego Gas and Electric's (SDG\&E's) Encina piant, Unit 5, has applied for a Section 316(a) variance. The Encina plant is a fossil-fuel plant with five units that discharge across the beach through both a riprap-lined channel and jetties into the Pacific Ocean. Units 1 through 4 are existing discharges and are in compliance with California's Thermal Plan. Unit 5, with a capacity of $315 \mathrm{MW}$, is considered a new discharge under the Thermal Plan and, as such, is subject to other specific limitations. If the variance from several of the Thermal Plan's discharge limitations for new dischargers is not approved, SDG\&E will be required to comply with those limitations. The most likely result would be the construction of an offshore pipeline for discharge to deep water. The capital cost of the pipeline is estimated at $\$ 38.2$ million in 1992 dollars.

Use of cooling towers at this location poses problems for several reasons. First, southern California has experienced severe shortages of fresh water; consequently, there is not enough fresh water to use as makeup water for the tower. Second, the prevailing winds would cause the cooling tower plume to drift inland over residential, commercial, and agricultural areas. The salt in the plume could cause problems for these other land uses. Finally, adequate space may not be available for construction of a cooling tower (Jacobsen 1992).

\subsection{SOUTHERN CAIIFORNIA EDISON}

Southern California Edison (SCE) operates the Songs plant on the Pacific coast south of Los Angeles. Unit 1 is considered an existing unit under the Thermal Plan and is in compliance with that plan. Units 2 and 3 are new nuclear units, with a combined capacity of 2,200 MW. Both use ocean water for once-through cooling. They do not require a Section 316(a) variance for normal operations, but they employ a biofouling control procedure callea heat treatment, in which the flow of cooling water is reversed for three to four hours 
per month: the hot water kills biofouling organisms in the intake system. A Section 316(a) variance is required to conduct the heat treating. SCE reported that if it was unable to continue heat treatment under a Section 316(a) variance, it would consider installing a cooling tower, at an estimated cost of $\$ 307$ million in 1992 dollars (Kay 1992).

\subsection{TENNESSEE VALLEY AUTHORITY}

The Tennessee Valley Authority (TVA) has seven coal-fired plants operating under with Section 316(a) variances. If the variance is lost, TVA will probably add helper cooling towers at each plant to function as part of a multimode cooling system. Table 1 gives retrofitting costs for TVA's coal-fired plants.

The John Sevier plant (800 MW) applied for a Section 316(a) variance in the $1970 \mathrm{~s}$, but no decision has been reached. The plant continues to operate under an interim decision. The cost to install a cooling tower is much higher there than expected, based on costs at other plants. The cost for the tower itself is $\$ 99$ million, but an additional $\$ 255$ million would be required to remove the existing retention dam, remediate sediments contaminated by upstream activities, and add a new intake structure.

TVA also has Section 316(a) variances at two nuclear plants. Both the Browns Ferry $(3,456 \mathrm{MW})$ and Sequoyah (2,442 MW) stations have already been retrofitted with multimode cooling towers. The variance allows the Browns Ferry plant to operate in a once-through cooling mode except during extremely hot or dry years. At the Sequoyah plant, the variance reduces the time that cooling towers must be used. If these plants lost the variance, TVA

\begin{tabular}{|c|c|c|}
\hline Plant & $\begin{array}{l}\text { Production Using } \\
\text { Once-Through } \\
\text { Cooling (MW) }\end{array}$ & $\begin{array}{l}\text { Retrofitting Cost } \\
(\$ \text { millions })\end{array}$ \\
\hline Bull Run & 950 & 114 \\
\hline Colbert & 1,350 & 148 \\
\hline Cumberland & 2,600 & 271 \\
\hline Gallatin & 1,255 & 133 \\
\hline Johnsonville & 1,485 & 162 \\
\hline Kingston & 1,700 & 168 \\
\hline Widows Creek & 1,969 & 204 \\
\hline
\end{tabular}


would install additional cooling towers to allo : full-time closed-cycle operation. The cost estimate for the retrofits is $\$ 54$ milion for Browns Ferry and $\$ 10$ million for Sequcyah (Schmierbach 1992).

\subsection{AMERICAN ELECTRIC POWFR SERVICE CORPORATION}

The American Electric Power Service Corporation (AEP) system has 10 coal-fired plants and 1 nuclear plant that currently operate with Section 316(a) variances. AEP also owns a portion of two other plants operated by the Ohio Valley Electric Corporation (Kyger Creek) and the Indiana-Kentucky Electric Corporation (Clifty Creek). If the variance is lost, all of these plants will be retrofitted with merhanical-draft cooling towers except for the Cook nuclear plant, which would add a natural-draft tower. The Breed plant ( $325 \mathrm{MW})$ will be retired by 1995, but it would be retired ei. lier if a cooling tower retrofit were required. Addition of cooling towers at the Gien Ly a plant is not feasible because of space constraints; therefore, Units 5 and 6 ( $35 \mathrm{MW}$ ) would be retired. Table 2 gives retrofitting costs for AEP's plants (AEP 1992).

TABLE 2 Retrofitting Costs for AEP's Plants Operating under Section 316(a) Variances

\begin{tabular}{lcc}
\hline \multicolumn{1}{c}{ Plant } & $\begin{array}{c}\text { Production Using } \\
\text { Once-Through } \\
\text { Cooling (MW) }\end{array}$ & $\begin{array}{c}\text { Retrofitting Cost } \\
\text { (\$ millions) }\end{array}$ \\
\hline Cardinal & 600 & 48 \\
Conesville & 415 & 22 \\
Cook & 2,110 & $485^{\mathrm{a}}$ \\
Kammer & 630 & 65 \\
Kanawha River & 400 & 30 \\
Muskingum River & 840 & 69 \\
Picway & 100 & 6 \\
Philip Sporn & 1,050 & 87 \\
Tanners Creek & 995 & 72 \\
Kyger Creek & 1,095 & 123 \\
Clifty Creek & 1,290 & 148 \\
\hline
\end{tabular}

a This cost estimate was not independently derived by AEP. Instead, AEP multiplied the $\$ 230 / \mathrm{kW}$ cost rate developed by Stone \& Webster (1992) by $2,110 \mathrm{NWW}$. 


\subsection{COMMONWEALTH EDISON}

Commonwealth Edison (CE) operates six plants with Section 316(a) variances. At four of the plants, CE believes it can comply with the existing state thermal water quality standards. At the other two plants, this mechanism will not work. The Dresden plant is a nuclear plant producing 1,666 MW of power. This plant has a small cooling pond on-site that would allow closed-cycle operation during the winter. For summer operation, the cooling pond would not be adequate and a cooling tower may be needed if Section 316(a) were deleted.

The second plant that would need to be changed is the coal-fired Kincaid plant (1,141 MW). The plant would need to be retrofitted with a cooling tower or its rate of power production would need to be reduced.

The estimated costs for adding cooling towers were not independently calculated, but were directly scaled up (by using a ratio of the generating capacities) from the cost to install a cooling tower at the 2,350-MW Byron station in 1976. This cost is on the low side since that cooling tower was an original installation and not a retrofit. The cost for the Byron tower was $\$ 74.5$ million in 1976 dollars. The scaled-up costs for the other plants in 1976 dollars are $\$ 52$ million for Dresden and $\$ 36$ million for Kincaid. Converted to 1992 dollars, these costs would be $\$ 106$ million for Dresden and $\$ 73$ million for Kincaid. This scaling-up approach assumes that the cost of original construction at a nuclear plant is the same as that at a fossil-fuel plant. In fact, the cost of construction at a nuclear plant may be greater (Yowell 1992).

The estimates also assume that costs are similar for a new installation and a retrofit. To check that assumption, data on both types of cooling towers were examined for AEP piants. Four AEP plants had newly installed cooling towers that averaged $\$ 48 / \mathrm{kW}$ (1992 dollars), after some allowances were made for overhead, carrying costs, electrical service costs, and the cost of revising intake structures. AEP provided cost estimates for retrofitting eight plants with cooling towers; these costs averaged $\$ 76 / \mathrm{kW}$. The ratio of retrofit to new installation was 1.7:1. If the cost estimates for the CE plants are multiplied by 1.7, the resulting costs are $\$ 180$ million for Dresden and $\$ 124$ million for Kincaid. However, this ratio is not completely accurate for these two CE plants because it reflects data for fossil-fuel plants, not for nuclear plants. Insufficient data were available for nuclear plants to calculate a more accurate ratio (Gaulke 1992). 


\section{NATIONAL ESTIMATE OF RETROFIT COSTS}

\subsection{SUMMARY OF DATA GATHERED}

Tables 3 and 4 provide a summary of the information for all of the plants that were discussed in Section 5. Because costs for construction at a nuclear plant are nearly always higher than those for comparable construction at a fossil-fuel plant, data are presented separately for the two fuel types. The cost per kilowatt, or cost rate, was calculated for each plant. The cost rates for fossil-fuel plants range from $\$ 32 / \mathrm{kW}$ to $\$ 346 / \mathrm{kW}$, with an average of $\$ 108 / \mathrm{kW}$ for 31 plants. The cost rates for nuclear plants range from $\$ 102 / \mathrm{kW}$ to $\$ 234 / \mathrm{kW}$, with an average of $\$ 171 / \mathrm{kW}$ for seven plants.

Figures 1 and 2 show plots of retrofit cost versus generating capacity for each fuel type. For fossil-fuel plants, most of the data points are tightly clustered along the line. Two obvious outliers are PEPCO's Chalk Point plant and FPC's Crystal River plant. No explanation was provided for the high cost rate for retrofitting these plants with cooling towers, but the plant layouts and the fact that estuarine or salt water would be used may be responsible factors. It is worth noting that PEPCO's cost rates for both mechanical-draft cooling towers $(\$ 346 / \mathrm{kW})$ and natural-draft cooling towers $(\$ 403 / \mathrm{kW})$ are the highest such rates reported in this study. Only the rate for mechanical-draft towers was considered in the data analysis.

The two outlying points, for the Chalk Point and Crystal River plants, were left in the data set for analysis and are probably balanced to some extent by the very low rates reported for two of the FP\&L plants. The Cape Canaveral plant had a cost rate of $\$ 32 / \mathrm{kW}$, and the Fort Myers plant had a rate of $\$ 42 / \mathrm{kW}$. The explanation provided by FP\&L for the relatively low rate was that their estimates did not include taxes, the cost of borrowed money, or the cost of replacing power during construction of the towers.

Linear regression analysis was performed on the data. The resulting regression equations and correlation coefficients $(r)$ are shown below.

$$
\begin{array}{llr}
\text { fossil-fuel plants } & y=0.105 x+2.2 & r \cdot 0.77 \\
\text { nuclear plants } & y=0.151 x+31.4 & r=0.53
\end{array}
$$

Lines representing these two equations are plotted on Figures 1 and 2, respectively. The regression line for fossil-fuel plants fits nicely and is statistically very significant (probability $<0.01$ ). On the other hand, the regression line for nuclear plants does not represent the data set precisely. It is not statistically significant (probability $=0.125$ ). ${ }^{5}$ This result is a function of the widely spread data points and the relatively small number of points $(N=7)$.

5 These probabilities represent the probability that the hypothesis (in this case, that the regression equation accurately expresses the distribution of data points) is incorrect. Generally, a probability $\leq 0.05$ is considered significant (the hypothesis is accepted), and a probability $<0.01$ is very significant. 
TABLE 3 Summary of Retrofitting Costs for Fossil-Fuel Units

\begin{tabular}{|c|c|c|c|c|c|}
\hline \multirow[b]{2}{*}{ Company } & \multirow[b]{2}{*}{ Plant } & \multirow[b]{2}{*}{ Fuel } & \multirow[b]{2}{*}{$\begin{array}{l}\text { Power } \\
(\mathrm{MW})\end{array}$} & \multicolumn{2}{|c|}{ Cost to Retrofit } \\
\hline & & & & $\begin{array}{l}\text { In Millions of } \\
1992 \text { Dollars }\end{array}$ & $\$ / \mathrm{kW}$ \\
\hline New England Power & Manchester Street & Gas/oil & 455 & 39 & 86 \\
\hline Baltimore G\&E & Crane & Coal/oil & 376 & 30 & 80 \\
\hline Baltimore G\&E & Wagner & Coal/oil & 989 & 70 & 71 \\
\hline $\mathrm{PEPCO}^{\mathrm{a}}$ & Chalk Point & Coal/oil & 710 & 246 & 346 \\
\hline Florida P\&L & Cape Canaveral & Gas/oil & 864 & 28 & 32 \\
\hline Florida P\&L & Fort Myers & Oil & 597 & 25 & 42 \\
\hline Florida P\&L & Cutler & Gas & 235 & 26 & 111 \\
\hline Florida Power Co. & Crystal River & Coal/nuc. & 964 & 256 & 266 \\
\hline Pacific G\&E & Mcss Landing & Gas/oil & 558 & 53 & 95 \\
\hline Pacific G\&E & Pittsburgh & Gas/nil & 1,302 & 143 & 110 \\
\hline Pacific G\&E & Contra Costa & Gas/oil & 1,260 & 110 & 87 \\
\hline San Diego G\&E & Encina & Gas/oil & 315 & 38 & 121 \\
\hline TVA & Bull Run & Coal & 950 & 114 & 120 \\
\hline TVA & Colbert & Coal & 1,350 & 148 & 110 \\
\hline TVA & Cumberland & Coal & 2,600 & 271 & 104 \\
\hline TVA & Gallatin & Coal & 1,255 & 133 & 106 \\
\hline TVA & Johnsonville & Coal & 1,485 & 162 & 109 \\
\hline TVA & Kingston & Coal & 1,700 & 168 & 99 \\
\hline TVA & Widows Creek & Coal & 1,969 & 204 & 104 \\
\hline TVA & John Sevier & Coal & 800 & 99 & 124 \\
\hline Amer. Electric Power & Cardinal & Coal & 600 & 48 & 80 \\
\hline Amer. Electric Power & Conesville & Coal & 415 & 22 & 53 \\
\hline Amer. Electric Power & Picway & Coal & 100 & 6 & 60 \\
\hline Amer. Electric Power & Kammer & Cnal & 630 & 65 & 103 \\
\hline Amer. Electric Power & Kanawha & Conal & 400 & 30 & 75 \\
\hline Amer. Electric Power & Muskingum River & Coal & 840 & 69 & 82 \\
\hline Amer. Electric Power & Philip Sporn & Coal & 1,050 & 87 & 83 \\
\hline Amer. Electric Pnwer & Tanners Creek & Coal & 995 & 72 & 72 \\
\hline Amer. Electric Power & Kyger Creek & Conal & 1,095 & 123 & 112 \\
\hline Amer. Electric Power & Clifty Creek & Coal & 1,290 & 148 & 115 \\
\hline Comm. Edison ${ }^{\mathrm{d}}$ & Kincaid & Conal & 1,141 & 124 & 109 \\
\hline Total & & & 29,290 & 3,157 & \\
\hline Overall Average & & & & & 108 \\
\hline
\end{tabular}

a PEPCO estimates that it would cost $\$ 346 / \mathrm{kW}$ for a mechanical-draft cooling tower and $\$ 403 / \mathrm{kW}$ for a natural-draft conling tower.

b The Crystal plant has both fossil-fuel and nuclear units. If FPC installed a conling tower, it would put it on the two fossil-fuel units or nn the nuclear unit, but not both. It wnuld most likely select the fossil-fuel units for the retrotit, so this plant is included on the list of fossilfuel plants.

- Conling towers cannnt be installed at the Encina plant. If the variance is Inst, SDG\&E will probably install an offishore nutfall pipe to deep water.

d Commonwealth Edison did not make independent cost estimates for its plants. Instead, it used the cost figures for a conling tower installed at its Byron plant in 1976 as a new installation. These costs were scaled up to approximate retrofit costs. 
TABLE 4 Summary of Retrofitting Costs for Nuclear Units

\begin{tabular}{|c|c|c|c|c|c|}
\hline \multirow[b]{2}{*}{ Company } & \multirow[b]{2}{*}{ Plant } & \multirow[b]{2}{*}{ Fuel } & \multirow[b]{2}{*}{$\begin{array}{l}\text { Power } \\
\text { (MW) }\end{array}$} & \multicolumn{2}{|c|}{ Cost to Retrofit } \\
\hline & & & & $\begin{array}{l}\text { In Millions of } \\
1992 \text { Dollars }\end{array}$ & $\$ / \mathrm{kW}$ \\
\hline \multirow{6}{*}{$\begin{array}{l}\text { GPU Nuclear } \\
\text { Virginia Power Co. } \\
\text { Virginia Power Co. } \\
\text { Carolina P\&L } \\
\text { Southern Calif. Edison } \\
\text { Amer. Electric Power }\end{array}$} & Oyster Creek & Nuclear & 640 & 150 & 234 \\
\hline & North Anna & Nuclear & 1,618 & 326 & 201 \\
\hline & Surry & Nuclear & 1,562 & 335 & 214 \\
\hline & Brunswick & Nuclear & 1,642 & 168 & 102 \\
\hline & Songs & Nuclear & 2,200 & 307 & 139 \\
\hline & Cook & Nuclear & 2,110 & 485 & 230 \\
\hline Comm. Edison ${ }^{\mathrm{c}}$ & Dresden & Nuclear & 1,666 & 180 & 108 \\
\hline \multirow{2}{*}{\multicolumn{2}{|c|}{$\begin{array}{l}\text { Total } \\
\text { Overall Average }\end{array}$}} & & 11,438 & 1,951 & \\
\hline & & & & & 171 \\
\hline \multicolumn{6}{|c|}{$\begin{array}{l}\text { Carolina Power and Light does not and will not operate under a Section } 316(\text { a) variance. } \\
\text { This estimate was derived in case it became necessary to install cooling towers to mitigate } \\
\text { impingement and entrainment impacts. }\end{array}$} \\
\hline \multicolumn{6}{|c|}{$\begin{array}{l}\text { b American Electric Power did not prepare an independent cost estimate for the Cook plant. } \\
\text { Instead it used the cost rate for nuclear plants reported in Stone \& Webster (1992). }\end{array}$} \\
\hline \multicolumn{6}{|c|}{$\begin{array}{l}\text { Commonwealth Edison did not make independent cost estimates for its plants. Instead, } \\
\text { they used the cost figures for a cooling tower installed at its Byron plant in } 1976 \text { as a new } \\
\text { installation. These costs were scaled up to approximate retrofit costs. }\end{array}$} \\
\hline
\end{tabular}

\subsection{ASSUMPTIONS FOR NATIONAL ESTIMATE}

The major assumptions made in deriving the national cost estimates are listed below.

- The individual costs used are those provided by the power companies. The few exceptions are noted in Section 5 . The cost estimates provided by the different power companies contained different levels of detail.

- All costs are expressed in 1992 dollars. Data provided in dollars from other years were converted to 1992 dollars by using the Engineering News Record (1992) Construction Cost Index.

- The total production capacity at risk if the Section 316(a) variance were deleted is $189,000 \mathrm{MW}$. Of this capacity, $146,000 \mathrm{MW}$ is at fossil-fuel plants, and 43,000 MW is at nuclear plants.

- The total costs were calculated by multiplying the total production capacity at risk by the applicable cost rate. 


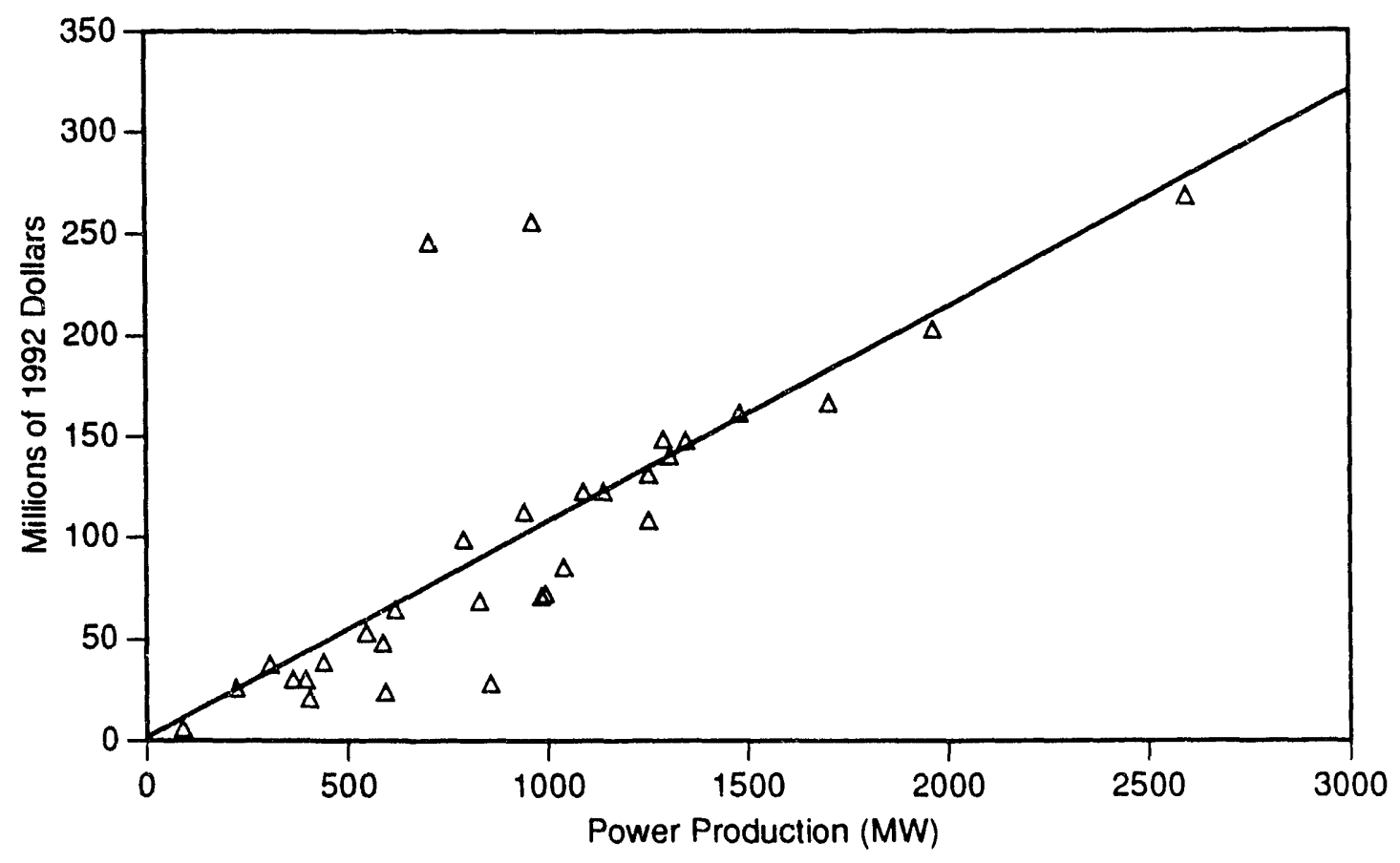

FIGURE 1 Capital Cost to Retrofit Fossil-Fuel Units with Cooling Towers

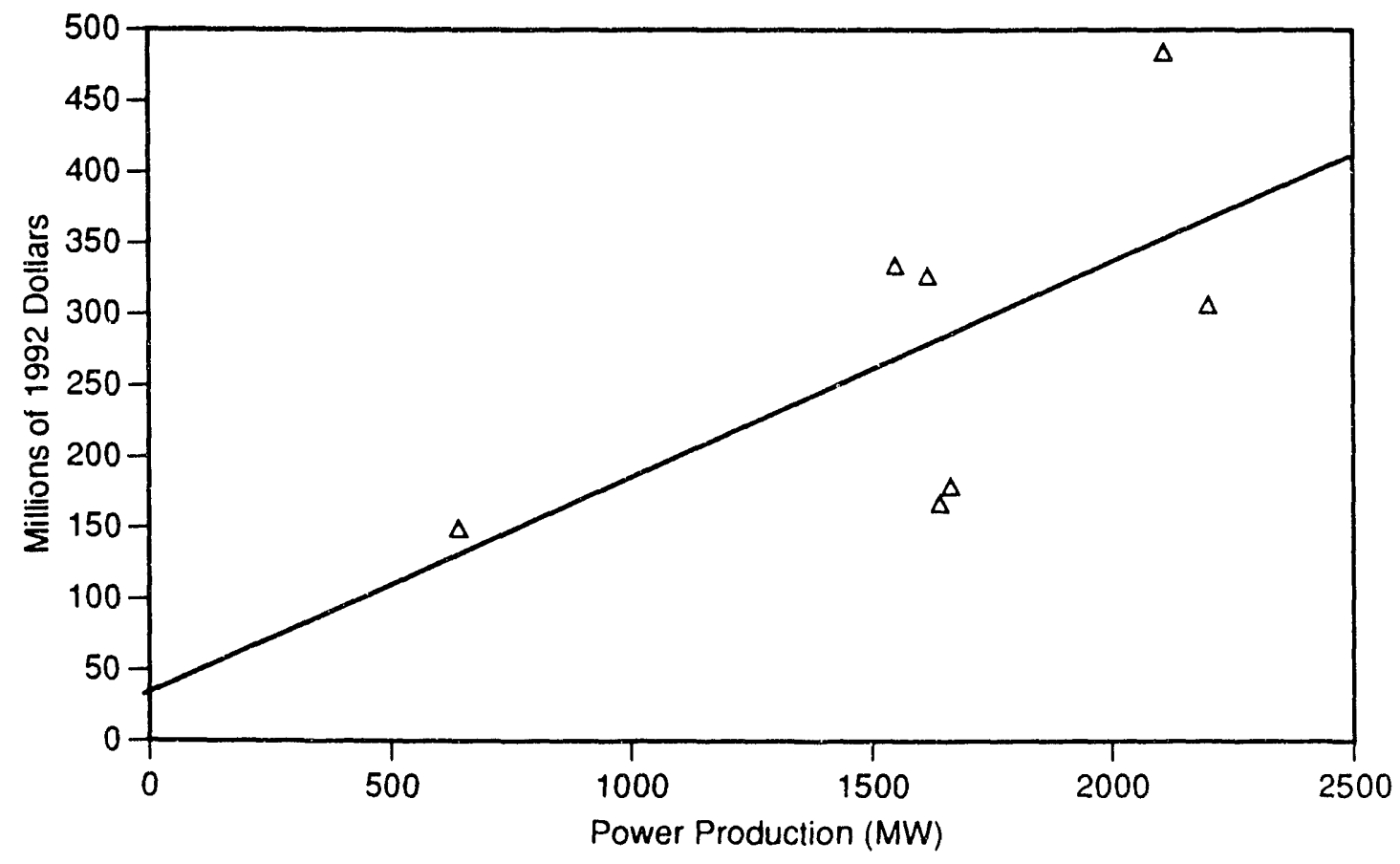

FIGURE 2 Capital Cost to Retrofit Nuclear Units with Cooling Towers 
- To estimate the national retrofit cost for fossil-fuel plants, both the average fossil-fuel cost rate $(\$ 108 / \mathrm{kW})$ and the slope of the fossil-fuel regression line $(\$ 105 / \mathrm{kW})$ were used.

- Since the slope of the regression line for nuclear plants is not a reliable indicator of the data set, other approaches were used to develop the national retrofit cost for nuclear plants. Both the average nuclear cost rate $(\$ 171 / \mathrm{kW})$ and the median nuclear cost rate $(\$ 201 / \mathrm{kW})$ were used.

- The costs estimated here are capital costs only. O\&M costs and the cost of replacement power were not included.

\subsection{FINDINGS}

If Section 316(a) of the CWA were eliminated and all plants currently operating under Section 316(a) variances were retrofitted with cooling towers, the data presented here indicate that the national capital cost would probably range from $\$ 15.3$ billion to $\$ 15.8$ billion for fossil-fuel plants and from $\$ 7.4$ billion to $\$ 8.6$ billion for nuclear plants. The combined total ranges from $\$ 22.7$ billion to $\$ 24.4$ billion in 1992 dollars. In comparison, Stone \& Webster's (1992) estimate for capital costs in 1992 dollars is $\$ 28.9$ billion (derived by examining two hypothetical plants and scaling up costs to the entire affected production capacity). Thirty-eight plants representing 14 power companies were evaluated during this study. They accounted for $39,086 \mathrm{MW}$ (or $21 \%$ ) of the 189,000 MW total national production capacity at risk. ${ }^{6}$ This sample is large enough to support a conclusion that the cost estimate is probably of the right order of magnitude.

The national cost estimates are based on solid technical data; however, the wide range of assumptions used has introduced some uncertainty. Even if the true costs are several times lower, the cost impact on the power industry of losing the Section 316(a) variance is still very large.

To accurately depict the cost burden to the power industry, the capital cost must be combined with O\&M costs and the cost of replacing lost power (including extra fuel and capital and O\&M costs for new production capacity). The replacement power cost, along with environmental benefits and environmental impacts, is reviewed in Veil et al. (1993), the companion to this report. That report concludes that conversion to cooling towers would decrease energy output by an estimated $1.0-4.6 \%$ at fossil-fuel plants and $1.0-5.8 \%$ at nuclear plants. The cost of additional generation to replace this lost output is estimated to be $\$ 11.4$ billion to $\$ 18.4$ billion over 20 years. The estimated cost of building additional generating capacity is $\$ 1.4$ billion to $\$ 5.3$ billion in 1992 dollars. The environmental benefits of eliminating the variance are minimal.

6 The 1,642 MW from CP\&L's Brunswick plant are not included in this total because this plant does not and will not need a Section 316(a) variance. 


\section{REFERENCES}

AEP, 1992, 1992 Clean Water (CWA) Reauthorization - Cost Analysis on the Impact to AEP System of Losing Section 316(a) Thermal Discharge Variance, American Electric Power Service Corporation, Columbus, Ohio, March.

Aull, R., 1992, personal communication, Ecodyne Research Cottrell, Santa Rosa, Calif., March 2.

Bailey, D.E., 1992, letter from Bailey, Potomac Electric Power Company, Washington, D.C., to J. Veil, Argonne National Laboratory, Washington, D.C., April 15.

Bauereis, E., 1992, personal communication, Baltimore Gas and Electric Company, Baltimore, Md.

Carwile, R., 1992, Aluminum Association, Washington, D.C.

CWA, 1972, "Clean Water Act (Federal Water Pollution Control Act)," Public Law 92-500, U.S. Code 33:1251 and following pages, as amended.

DeHart, B., 1992, personal communication, New England Power, Westboro, Mass.

EEI, 1989, Power Statistics Database, maintained by the Utility Data Institute, Washington, D.C., for Edison Electric Institute, Washington, D.C.; accessed by Stone \& Webster (1992).

Engineering News Record, 1992, "Construction Cost Index," McGraw-Hill, New York, N.Y., p. 43, March 30 .

EPRI, 1991, Dry Cooling: Perspectives on Future Needs, EPRI GS-7446, Electric Power Research Institute, Palo Alto, Calif.

Fidler, K., 1992, Chemical Manufacturers Association, Washington, D.C.

Gaulke, A., 1992, letter from Gaulke, American Electric Power Service Corporation, Columbus, Ohio, to J. Veil, Argonne National Laboratory, Washington, D.C., April 15.

Gillespie, B., 1992, National Council of the Paper Industry for Air and Stream Improvement, New York, N.Y.

Greeson, M., 1992, personal communication, Carolina Power and Light, Raleigh, N.C.

Indiana State Board of Health, 1985, Variance under Section 316(a) of the Clean Water Act, permit no. IN0001155, issued to Aluminum Company of America by the Indiana State Board of Health, effective October 30, 1985. Currently administered by the Indiana Department of Environmental Management. 
Jacobsen, F., 1992, personal communication, San Diego Gas and Electric Company, San Diego, Calif.

Kay, D., 1992, personal communication, Southern California Edison, Rosemeade, Calif.

Kunkle, K., 1992, personal communication, GPU Nuclear Corp., Reading, Penn.

Laffley, G., 1992, personal communication, American Petroleum Institute, Washington, D.C.

Maryland DHMH, 1985, Variance under Section 316(a) of the Clean Water Act, permit no. 79-DP-0064, issued to Bethlehem Steel Corporation by the Maryland Department of Health and Mental Hygiene, Baltimore, Md,, effective October 10, 1985. Currently administered by the Maryland Department of Environment, Baltimore, Md.

Maryland DHMH, 1986a, Variance under Section 316(a) of the Clean Water Act, permit no. 85-DP-0376, issued to Amstar Sugar Corporation by the Maryland Department of Health and Mental Hygiene, Baltimore, Md., effective March 21, 1986. Currently administered by the Maryland Department of Environment, Baltimore, Md.

Maryland DHMH, 1986b, Variance under Section 316(a) of the Clean Water Act, permit no. 81-DP-0277, issued to Nevamar Corporation by the Maryland Department of Health and Mental Hygiene, Baltimore, Md., effective July 22, 1986. Currently administered by the Maryland Department of Environment, Baltimore, Md.

MDE, 1989, Variance under Section 316(a) of the Clean Water Act, permit no. 88-DP-2119, issued to Baltimore RESCO by the Maryland Department of Environment, effective March 27, 1989.

Pardue, J., 1992, personal communication, Florida Power Company, St. Petersburg, Fla.

Perkins, W., 1992, personal communication, Florida Power and Light, West Palm Beach, Fla.

Schmierbach, M.P., 1992, letter from Schmierbach, Tennessee Valley Authority, Knoxville, Tenn., to J. Veil, Argonne National Laboratory, Washington, D.C., March 26.

Steiner, B., 1992, American Iron and Steel Institute, Washington, D.C.

Stone \& Webster, 1992, Evaluation of the Potential Costs and Environmental Impacts of Retrofitting Cooling Towers on Existing Steam Electric Power Plants That Have Obtained Variances under Section Section 316(a) of the Clean Water Act, prepared for Edison Electric Institute, Washington, D.C.

U.S. Environmental Protection Agency, 1990, "Steam Electric Power Generating Point Source Category," Code of Federal Regulations, title 40, part 423, pp. 727-736. 
U.S. Environmental Protection Agency, 1990, "Criteria and Standards for the National Pollutant Discharge Elimination System," Code of Federal Regulations, title 40, part 125, pp. 190-227.

U.S. Senate, 1991, "Water Pollution Prevention and Control Act of 1991," S. 1081, 102nd Congress, 1st session, May.

U.S. Senate, 1991, "Water Pollution Prevention and Control Act of 1991," S. 1081, 102nd Congress, 1st session, Majority Staff Draft, December 31.

Veil, J.A., 1989, "Point Source Controls, Permits, and Pretreatment - Maryland's Perspective," paper 5-1 in conference proceedings for The Chesapeake at Risk: Towards a Toxic Strategy, sponsored by the Alliance for Chesapeake Bay, Baltimore, Md., held in Richmond, Va., October 1988.

Veil, J.A., et al., 1993, Impact on the Steam Electric Power Industry of Deleting Section 316(a) of the Clean Water Act: Energy and Environmental Impacts, report ANL/EAIS-5, Argonne National Laboratory, Argonne, Ill., January.

Walton, C.P., 1992, letters from Walton, Pacific Gas and Electric Company, San Francisco, Calif., to J. Veil, Argonne National Laboratory, Washington, D.C., April 15 and April 17.

White, J., 1992, personal communication, Virginia Electric Power Company, Richmond, Va.

Yowell, D., 1992, personal communication, Commonwealth Edison, Chicago, Ill. 


\section{DISTRIBUTION FOR ANL/EAIS-4}

\section{Internal}

ANL Patent Department

K.S. Macal (6)

ANL Technical Publications

J.A. Veil (27)

\section{External}

U.S. Department of Energy Office of Scientific and Technical Information (12)

Manager, U.S. Department of Energy Chicago Field Office

ANL-E Libraries

ANL-W Library 

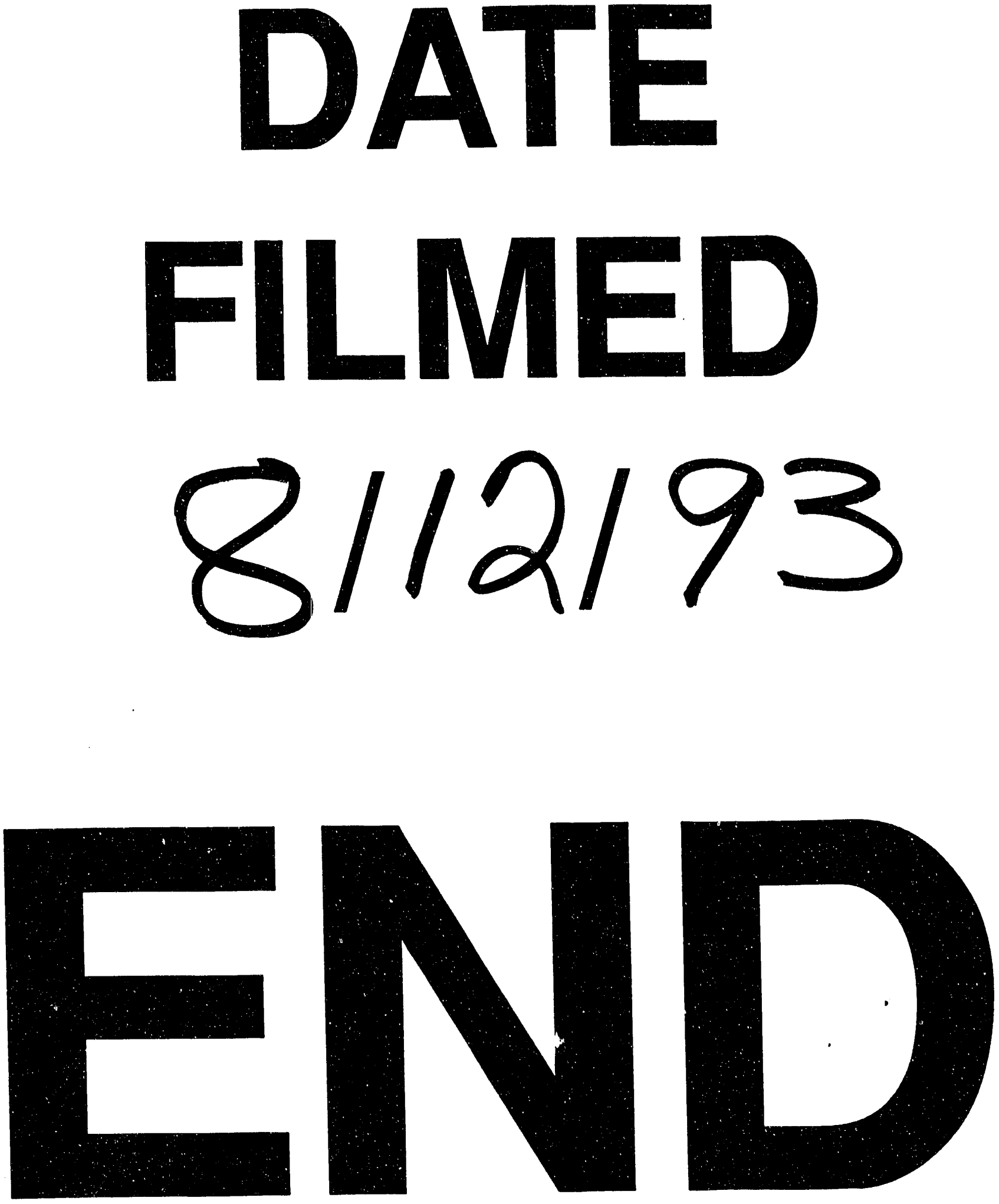
